\title{
Partisanship versus Democracy: Voting in Turkey's Competitive Authoritarian Elections
}

\section{Tijen Demirel-Pegg}

Aaron Dusso

\begin{abstract}
Do voters care about anti-democratic behavior by their leaders? While political pundits and academics often hope that they do, there has been little research that tests the effects that specific anti-democratic actions have on voters during elections. This is because there are few clear instances where violations of democratic norms are so visible to the average voter that one would expect it to have an effect; above and beyond traditional predictors of the vote. However, the recent elections in Turkey offer a unique opportunity to test the effect that nullifying an entire election (an unequivocal violation of democratic norms) has on voters. We do exactly that with a survey of voters following the election re-do. We find that even in such an extraordinary circumstance, voters rely on standard voting drivers like partisanship, rather than concern for the functioning of democracy itself. Ultimately, our findings have important implications for voting in competitive authoritarian regimes, as they fail to show that anti-democratic behavior is punished.
\end{abstract}

\section{Published Online in Political Studies Review}

This is the authors' manuscript of the article to be published in final edited form at:

Demirel-Pegg, Tijen and Aaron Dusso (2021), "Partisanship versus Democracy: Voting in Turkey's Competitive Authoritarian Elections" Political Studies Review.

https://doi.org/10.1177/14789299211030446. 


\section{Introduction}

On June 23, 2019, Istanbul voters handed Turkish President Recep Tayyip Erdoğan a second electoral defeat in less than three months. This defeat came as Istanbul residents elected the main opposition candidate, Ekrem İmamoğlu, from the People's Republic Party (CHP) to be mayor. The incumbent Justice and Development Party (AKP)'s candidate Binali Y1ldırım had already lost in the first set of elections on March 31. The local elections on March 31 were a major disappointment for AKP and President Erdoğan because of their loss of municipal governments in several major cities. Yet, the ruling party's electoral defeats in Istanbul, the economic powerhouse of Turkey, and Ankara, the capital, attracted significant attention because of AKP's hitherto long-lasting control of them (McKernan, 2019). AKP conceded power to the newly elected local officials in most areas, including Ankara, but not in Istanbul. AKP challenged İmamoğlu’s narrow victory and successfully pressured Turkey's electoral authority, the Supreme Electoral Council (YSK), to overturn the Istanbul elections, citing the inclusion of non-civil servants in supervisory committees at the polling booths. As a result, on June 23, Istanbul residents voted again and gave İmamoğlu a decisive 54\% win over Yıldırım (McKernan, 2019).

In an increasingly authoritarian context, the ballot box remains one of the last democratic mechanisms available to Turkish citizens to express their political preferences. AKP's repression of opposition movements, its severe limitations of freedom of the press, and its politicization of state institutions, including the judiciary, have enabled the government to tighten its grip on power, particularly since 2010 (Esen and Gümüşçü, 2016). Yet, the electoral process had remained mostly competitive, allowing Turkish citizens to exercise their political voice with 
confidence. The unwillingness of President Erdoğan to concede power in Istanbul and his concerted pressure on state institutions to nullify the election threatened Turkish citizens' sole remaining means for democratic participation (Esen and Gümüş̧̧ü, 2019).

The popular narrative surrounding the second election framed İmamoğlu's win as a sign of Turkish citizens' commitment to democracy (Esen and Gümüşçü, 2019; McKernan, 2019). For example, The Economist encouraged Istanbul residents to vote for İmamoğlu by stating that "[A]nyone in Istanbul who cares about the survival of democracy in Turkey, including all but the most narrow-minded supporters of the ruling AK party, ought to turn out in their millions to vote for the rightful mayor” (The Economist, 2019a). On Open Democracy’s website, Kadıoğlu highlighted "[T]he inspiring stories of elderly citizens of Istanbul who went out of their ways to vote... [which] revealed how the memory of the struggle for democracy could be instrumental in the fight for it" (Kadığlu, 2019). Similarly, in its coverage of the election outcome, The New York Times quoted an analyst highlighting the vote as a sign of democratic resilience (Gall, 2019).

However, without systematic evidence to back up these claims, these antidotes may be more representative of journalists' confirmation bias than a groundswell of support for democracy itself. A glance at the electoral tabulations shows that $45 \%$ of the voters still chose AKP's Yıldırım, a high percentage given that AKP violated fundamental democratic norms by nullifying the first election. Polls show that only $1-2 \%$ of the Istanbul electorate shifted their votes from Yıldırım to İmamoğlu in the second round (Konda, 2019). Moreover, voter turnout for the second election $(84.4 \%$ ) was similar to the nullified election $(83.8 \%)$. Thus, while the annulment did not appear to turn citizens off from participating, it appears to have energized only a tiny segment of voters in the second round. Ultimately, İmamoğlu's more decisive victory in 
June can be explained by the decrease in the number of invalid votes (from 3\% in March to 1.7 $\%$ in June), a decrease in AKP turnout (3.7\%), and a shift of 1-2 \% of votes from Y1ldırım to İmamoğlu (Konda, p. 4). These figures call into question the dominant narrative that democracy itself was reaffirmed by the actions of the Istanbul electorate.

Recent work on democratic backsliding and executive takeover suggests a more circumspect interpretation of what happened in Istanbul during these two elections than has been presented in the popular press. Svolik (2020) shows that in a sharply polarized political context, voters are more willing to forgo fair democratic competition in favor of their preferred party and an incumbent who stands for their personal interests, even though these politicians subvert democracy. While the literature on civic participation and social capital generally assumes that the public serves as a check against a non-democratic leader (Almond and Verba, 1963), we agree with Svolik $(2019,2020)$ and McCoy, Rahman, and Somer (2018) that this expectation may not be fulfilled in polarized societies because voters are often asked to choose between democratic values and partisan interest. The incidents of democratic backsliding in Hungary, Turkey, and Venezuela and the continued appeal of Donald Trump after his repeated lies about the results of the 2020 presidential election are examples of the triumph of partisan interests over concerns about democratic institutions.

Following Svolik's (2020) work, we argue that in the Turkish mayoral elections, even though the non-democratic candidate of the incumbent party lost the elections in Istanbul, the election results were still a function of partisanship rather than a commitment to democratic values. We put the popular narrative to the test with a survey administered to Istanbul voters shortly after the June election. The survey taps respondents' concern for democratic functioning as well as traditional scholarly predictors of election outcomes, i.e., partisanship and 
respondents' thoughts on the state of the economy (Bartels, 2000; Bartkowska and Tiemann, 2015). The timing of the survey is important because if worries about the erosion of democratic principles were the main motivation for Istanbul residents to participate in the elections and vote for the opposition candidate, our survey would capture these sentiments after widespread media coverage of the damaging democratic consequences of electoral nullification. Our findings, however, demonstrate that partisanship, and not concerns for democracy, determined how people voted in the second election. This is an important finding as misinterpreting these election results as a defense of democracy would lead individuals to believe that Turkey's democracy is on a stronger footing than it really is. Ultimately, our analysis indicates that voters in a competitive authoritarian regime, like Turkey, behave similarly to their counterparts in democratic ones. That is, partisanship is the primary driver of voting behavior, even when democracy itself is at stake.

\section{The 2019 Local Elections in Turkey}

Authoritarianism has been on the rise throughout the last decade in Turkey, long before the 2019 local elections. Having maintained strong popular support since coming to power in 2002, AKP won the highest number of parliamentary seats in five out of six general elections and kept its control of the majority of local metropolitan areas and districts until 2019. With a strong democratic mandate, AKP initiated an assertive legal agenda and passed an unprecedented number of laws rapidly without much public scrutiny. While AKP promised to strengthen individual rights and freedoms against the traditionally strong state with these reforms, the party used its democratic mandate to undercut institutions of accountability over time (Bermeo, 2016: 11). 
The first signs of democratic backsliding began in 2004 when the government limited freedom of the press by changing the penal code to allow the criminal prosecution of journalists (Bermeo, 2016). Over time, regular censorship of media outlets, curtailment of civil liberties, especially freedom of expression, and holding unfair elections have demonstrated an alarming trend toward further democratic backsliding. Following a failed coup attempt in July 2016, President Erdoğan declared emergency law and purged thousands of military and administrative personnel from various governmental bodies. One year later, while still under emergency law, major constitutional amendments were passed in a referendum that changed Turkey's political system from a parliamentary to an executive presidential system with weak checks and balances. Since then, democratic backsliding has intensified with unceasing executive control and political influence over the judiciary, the continued misuse of terrorism charges to suppress the opposition, severe restrictions on the right to assembly, and constant suppression of independent media outlets (Human Rights Watch, 2020).

In addition, the AKP regime polarized the country socially and politically (Somer, 2019). The consistent AKP narrative to redefine the society based on Islamic principles and its deliberate policies to dominate state institutions polarized the secular circles. With the inability of the opposition to unite against the government, AKP deepened the cleavages between these pro-secular and religious poles by urging people to choose sides and discourage attempts to find a middle ground (Somer, 2019: 52). Erdoğan's use of sharp rhetoric, asking his supporters to interpret political events along these cleavages, solidified the pro and anti-AKP camps (McCoy et al., 2018: 32).

Against this backdrop, local governance has played a crucial role in providing AKP a major electoral advantage over the years (Kemahlığlu and Özdemir, 2018). Through the control 
of local municipalities, AKP distributes social policy programs and resources strategically to selected neighborhoods based on their potential to generate pro-AKP votes (Kemahlığlu and Özdemir, 2018). Therefore, controlling municipal districts has been an important pillar of AKP's political support.

The 2019 local elections were also important for AKP for economic and political reasons. Economically, the country had just entered a recession with the value of the Turkish lira weakening by about $30 \%$ in one year, producing the worst inflation rate that the country has experienced under AKP's leadership (The Economist, 2019b). The recession threatened AKP's popularity (Esen and Gümüşçü, 2019). If AKP lost local districts to the opposition, its ability to deliver social services to the poor or benefits to businesses in a clientelistic manner would diminish. Politically, AKP faced a challenge from a unified opposition. Ironically, AKP spearheaded an electoral amendment in 2018 allowing parties to unify before general and municipal elections. CHP, the center-left opposition party, appealed to a wider range of the ideological spectrum, and allied with IYI Parti (center right), Demokrat Parti (center-right) and Saadet Partisi (Islamist), while AKP formed an alliance with the nationalist Milliyetci Hareket Partisi (MHP). The Kurdish People's Democracy Party (HDP) declared its support for CHP candidates in several municipalities in western cities of Turkey, giving CHP's alliance a critical advantage in a tight election.

The combination of economic problems and CHP's ability to unify a wide range of voters from different opposition parties (most importantly the Kurdish votes) threatened AKP's control of major municipalities. When AKP lost the local elections in Istanbul on March 31, President Erdoğan refused to accept the results and pressured the Supreme Electoral Council to nullify 
them. The second election held on June 23, however, delivered AKP a 10-point defeat (44.9 percent for Yıldırım to 54.2 percent for İmamoğlu), ending its 25-year long control in Istanbul.

\section{Voting Behavior in Competitive Authoritarian Regimes}

Contested elections are one of the major characteristics that distinguish competitive authoritarian regimes from fully authoritarian or single-party regimes. In fully authoritarian regimes, elections serve three objectives. First, elections are a signal to potential defectors of the strength of the authoritarian regime (Geddes et al., 2018). Second, they provide the leader information about the performance of local officials. Low voter turnout, for instance, informs the central government that local officials have failed to bring citizens out to vote (Gandhi and LustOkar, 2009). Finally, elections allow the central government to allocate resources to loyal elites or use resources to buy loyalty. (Svolik, 2012). Thus, elections are neither fair nor competitive in fully authoritarian regimes.

However, in competitive authoritarian systems elections are competitive, but not fair. According to Levitsky and Way (2002), these regimes allow opposition parties to participate in the electoral process; yet, the playing field is skewed in favor of incumbents. Governments can boost the incumbent parties' campaigns by resorting to tactics such as limiting the opposition's access to media outlets, using government funds for incumbent campaigns, and harassing opponents. The elections themselves do not appear to be fraudulent; yet, they are not fair because the government's opponents are denied equal opportunity to campaign (Bermeo, 2016).

A major reason Turkey is considered a competitive authoritarian regime is its biased electoral process (Esen and Gümüşçü, 2016). While elections are open to opposition parties, the 
playing field is uneven because the government ensures that contending parties do not have an equal chance of winning elections. Primarily, AKP has increased its partisan control over the main electoral body, YSK, allowing AKP to weaken or co-opt political rivals and to constrain their ability to win elections. For example, the YSK changed the electoral law in 2018 to include a provision allowing for interparty alliances. Thus, AKP could join forces with the nationalist MHP and form the government after the 2018 elections, which it would not have otherwise been able to do on its own (Freedom House, 2019). Crucially, the YSK refuses to investigate any allegations of electoral abuse brought up against AKP (Esen and Gümüşçü, 2016).

Moreover, AKP sidelines the opposition by limiting their access to media outlets during election campaigns. AKP gets significantly more air time on state-owned television, i.e., the Turkish Radio and Television Corporation (TRT). TRT allocated 59 hours of coverage to AKP, 5 hours to CHP, 70 minutes to MHP, and only 18 minutes to the Kurdish Party, HDP before the 2015 parliamentary elections (Sayar1, 2016). A month before the local elections in March 2019, the AKP-MHP alliance received over 53 hours of positive coverage while the opposing alliance received only 14 hours of coverage, of which 7 hours was negative. (Sendika.Org, 2019). Likewise, media organizations with ties to the government devoted disproportionately more air time to the AKP campaign (Esen and Gümüş̧̧ü, 2019).

Finally, the use of blatant repressive tactics against the Kurdish party, HDP, exemplifies AKP's attempts to skew the playing field in its favor. Although the government adopted a conciliatory approach toward the Kurds in its early years in power, HDP's increasing popularity threatened AKP's nationalist wing and the nationalist party MHP. In all elections held since 2014, the HDP campaign has been targeted by the government and its allies. For instance, before the general elections of June 2018, the HDP reported 114 assaults resulting in 18 deaths, 
54 wounded, 394 detained, and 18 arrested (Toktamis and David, 2018). Several HDP

parliamentarians, including its former co-leader Demirtaş, were detained in November 2016, which forced Demirtaş to campaign for the 2019 local elections from prison. All told, AKP's moves to reduce its chances of losing elections signifies that Turkey is increasingly a competitive authoritarian regime.

Despite an uneven playing field, elections provide the Turkish citizens the opportunity to vote the competitive authoritarian governments out of office. Competitive authoritarian regimes, fairly or not, claim a democratic mandate. But, if an incumbent government nullifies election results based on flimsy evidence, will this overt rejection of the will of the people, motivate citizens to vote against the ruling party, regardless of voters' partisan leanings? If concern for democracy does not drive voters of competitive authoritarian systems, what factors determine if they participate in the elections and for whom they vote? To answer these questions, we turn to well-established research on what drives voting behavior.

\section{Classic Drivers of Voting Behavior versus the Popular Narrative}

Beyond Turkey's particular electoral context, scholars have developed a good understanding of the variables that consistently drive electoral outcomes in modern democracies. The most prominent are individuals' durable partisanship and ideological leanings and their more context-based feelings about the state of the economy (Aytaç and Çarkoğlu, 2018; Berz, 2020; Fleury and Lewis-Beck, 1993). Turkey is no exception to these findings. For example, Çakır (2019) finds that Turkey exhibits high partisanship, which has a significant influence on the choices made by voters. Indeed, of particular relevance to our work is Kalaycığglu (2014) who 
examines the effect of partisanship in local elections in 2009 and 2014. He shows that voters were driven by a combination of their partisanship, ideology, and economic dissatisfaction. In contrast, Akarca (2019) finds that the ability of voters to hold elected officials accountable for the state of the economy depends on whether there is a single-party or coalition government. Thus, research clearly shows that voters in Turkey behave in a similar way to voters in other electoral contexts. But was there something special about the annulment of the March election results in Istanbul and subsequent June election, that might have roused voters from their standard voting heuristics and led them to reject AKP's actions in this case?

We contrast the standard scholarly understanding of what drives voters with the popular press narrative of voters responding to a challenge by AKP to the legitimacy of democratic elections. If citizens were driven to the polls to protect their democracy, then it should show up in our data. Thus, we put this supposition to the test versus the traditional scholarly understanding of what drives voters, i.e., their partisanship and feelings about the economy. This results in the following hypotheses:

H1a (turnout): The more concerned about democratic processes one is, the more likely one is to turnout to vote.

H1b (vote choice): The more concerned about democratic processes one is, the less likely one is to vote for the AKP candidate.

H2a (turnout): The stronger one's partisanship, the more likely one is turnout to vote.

$\mathrm{H} 2 \mathrm{~b}$ (vote choice): The more one identifies with AKP/CHP, the more likely one is to vote for the $\mathrm{AKP} / \mathrm{CHP}$ candidate.

H3a (turnout): The worse one believes the economy to be, the more likely one is to turnout to vote. 
H3b (vote choice): The worse one believes the economy to be, the less likely one is to vote for the AKP candidate.

\section{Data and Methods}

\section{Data and Methods}

To test our hypotheses, we administered a survey of eligible voters after the June 2019 Istanbul mayoral election. The survey was in the field from June 29 to July 8, 2019. We contracted with Dynata to provide our survey respondents. Dynata is a for-profit public opinion corporation that maintains panels of consumers across the globe. Dynata's (formally known as Survey Sampling International) consumer panels have regularly been used by scholars across numerous disciplines to provide high-quality respondents to academic surveys (Bansak et al., 2021). Online surveys have become common and scholars have found their results to vary from traditional survey methods. For example, Karp and Luhiste (2016) show that online surveys produce higher estimates of political engagement than the American National Election Studies Survey (ANES) and British Election Study while Valentino et al. (2020) demonstrate that online respondents tend to be more politically conservative and less open to experience. Thus, there is reason to be cautious in interpreting the data from our online survey.

Our survey relies on a quota system to draw a sample from the Istanbul voting-eligible population and, thus, is not a representative sample. We are not attempting to report aggregate level information (e.g., vote totals by party, or turnout by gender), but rather are interested in the individual level drivers of citizens' decisions. Therefore, a representative sample of the population is not required (Iyengar and Westwood, 2015; Passini, 2017). Specifically, this data can answer whether partisanship influenced vote choices, but it cannot tell us the distribution of 
partisanship in the electorate. Our sample was drawn to approximate the distribution of voters on three key variables: gender, age, and ethnicity. The survey was designed and hosted in Qualtrics. The questions were originally written in English, drawing from standard question wordings used in ANES and the European Social Survey (ESS). The questions were then translated by one of the authors, who is a native Turkish speaker and fluent in English. The survey was administered solely in Turkish. Table 1 presents descriptive statistics for each of our variables.

***Table 1 here****

\section{Dependent Variables}

We utilize several operationalizations of the dependent variable to fully examine the effect that concern about democracy has on voters' choices to turn out to vote and whom to vote for. First, we use a dummy variable for turnout coded 1 , if individuals voted and 0 otherwise. Second, we test vote choice with two dummy variables. The first is coded 1, if respondents voted for the AKP candidate and 0 otherwise. The second is coded 1 , if respondents voted for the CHP candidate and 0 otherwise. These two operationalizations isolate the choice to vote for the specific party candidate when compared to all other options. But we suspect that the effect of respondents' concerns about democracy will be most prominent when comparing the decision to choose between just AKP and CHP candidates since these are the two main parties. To focus specifically on the choice between AKP and CHP, we estimate a 4-point multinomial logit model predicting the simultaneous choice to not vote or vote for one of the available candidates. This variable is coded 0 if the respondent did not vote, 1 if they voted for AKP, 2 if they voted for the CHP, and 3 if they voted for any other party's candidate. This final operationalization works on the assumption that the choice to turnout and the choice of whom to vote for occur simultaneously in the minds of citizens (Driscoll and Nelson, 2014; Kalmoe and Piston, 2013). 
All told, by utilizing these four dependent variables, we can alleviate concern that our results are driven by our model specification.

\section{Key Independent Variables}

To capture respondents' concern for democracy we included three separate questions in our survey. The first is an open-ended question that follows ANES' long-running most important problem question. It asks respondents the following: "What do you think are the most important problems facing the country?" This question has also been asked in Gallup public opinion surveys for decades and in the Eurobarometer (Edy and Meirick, 2018; Hoerner and Hobolt, 2019). This question came early in the survey after we asked about presidential job approval, news consumption, and whether they voted in either mayoral election. Respondents were free to say as much or as little as they liked, without our question priming any particular topic. The responses were then coded for any attempt to indicate that the respondent is concerned about the functioning of democracy.

We applied a liberal definition of this concern. In addition to direct references to "democratic concerns" we also looked for words such as "dictatorship", "one-man governance", "electoral concerns", and "lack of separation of powers." Overall, about 5 percent of respondents were coded as mentioning some type of concern about the functioning of democratic processes. Thus, this variable is coded 1 if it was mentioned and 0 otherwise. We believe this is the best measure of concern for democracy because it is open-ended. It does not prime the issue or force individuals to answer questions specifically about democratic functioning, which respondents would answer, not because it was on the top of their minds, but because we asked. 
While the open-ended question allows us to capture respondents' most salient concerns, it may not capture all of a respondent's concerns. Therefore, we asked two more direct questions about respondents' thoughts about nullifying the March election's results and whether they thought the June election was run under fair conditions. The exact question wording for the former is: "As you know, the Elections Commission nullified the results of the March 31st Istanbul mayoral election, which resulted in a new election held on June 23rd. Do you agree with the Election Commission's decision to nullify the election, or do you disagree with the Election Commission's decision to nullify the election?" Respondents were also given the option to answer don't know, and the agree/disagree options were randomly presented, listed either first or second. The second question was worded as follows: "Do you believe or not believe that the election campaigns for the candidates for the mayoral elections in Istanbul held on June 23, 2019 were run under fair conditions?" Respondents were given a standard 5-point Likert scale ranging from strongly agree to strongly disagree.

\section{Control Variables}

We include numerous control variables that have been consistent predictors of turnout and vote choice. For each of these questions, we followed standard question wordings found in the ANES and/or ESS. First is a measure of presidential approval, a 3-point scale from disapprove (coded 0) to approve (coded 2). Next is ideology, which is an 11-point scale ranging from extremely liberal on the left (coded 0 ) to extremely conservative on the right (coded 10). Since Turkey is a multiparty system, we follow the ESS's method of asking respondents their propensity-to-vote (PTV) for each party on a 0 (never) to 10 (always) point scale. This method was introduced by van der Eijk et al., (2006)) and has been used regularly by scholars measuring partisanship in multiparty systems (Angelucci et al., 2020; Meeusen et al., 2017). Indeed, Paparo 
et al. (2020) demonstrate its applicability to the US context, with improved predictability over traditional ANES methods of measuring partisanship. We asked the PTV question for each of the top eight parties holding seats in the Grand National Assembly. We also include a measure of political knowledge. This is obtained by following ANES' method of asking respondents several factual political questions and then summing each respondent's correct answers. The questions were to (1) identify the party in the Grand National Assembly with the most seats, (2) the current unemployment rate in Turkey, (3) which political party President Erdoğan belonged to, (4) and an open-ended question asking respondents to identify the political position that Mustafa Şentop (Speaker of the Grand National Assembly) now holds. This resulted in a political knowledge scale that runs from 0 (all questions wrong) to 4 (all questions correct).

We also included variables tapping respondents' religion and religious attitudes. First, we include respondents' religious identification as dummy variables (Sunni, Alevi, Caferi, other), second, is a measure of their frequency of worship coded from 0 (never) to 5 (more than once a week), and third, we include a measure of the importance of religion to them coded 0 (not important) to 4 (extremely important). We also include measures of respondents' news consumption and interest in politics. This consists of three variables. Each of these variables captures the frequency of the respondents' watching TV news, talking about politics, and using social media. Each of these variables is coded from 0 (never) to 7 (every day of the week). Finally, we include several basic demographic variables: ethnicity coded 1 for Turkish and 0 otherwise; age coded from $0(18-29)$ to 5 (70 or older); gender coded 1 for man and 0 for woman; household income coded 0 to 5 (least to most); and education coded 0 to 5 (least to most). Basic descriptive statistics for each of these variables can be found in Table 1. Exact question wordings can be provided upon request. 


\section{Results}

An open-ended survey question is the primary method by which we test the popular notion that anti-democratic policies (such as nullifying an election) will raise citizens' concerns about the functioning of their democratic institutions, which will ultimately lead voters to "punish" the anti-democratic behavior during the next election (hypotheses H1a and H1b). The results of our survey cast doubt on that supposition, with just 5 percent of respondents mentioning concern about democratic functioning, i.e., a total of 99 respondents out of 1,957 who answered the question. This is the case even though our survey took place just a week after a second election was held within months of the Supreme Electoral Council, upon Erdoğan and AKP's insistence, nullifying the first election. Of the 99 respondents who mentioned a problem with this turn of events and also answered our question tapping their attitude towards canceling the first election, zero said they agreed with the cancelation. Of those 99 who also answered if they thought the second election was conducted fairly, 75 either disagreed or strongly disagreed, while just 16 answered that they either agreed or strongly agreed. Of the 99,78 said they voted in the second election, while 75 said they voted in the first election. Finally, 78 of the 99 respondents were willing to answer who they voted for in the second election. The vast majority of these respondents (74 out of 78) indicated that they voted for the CHP candidate, while only 2 respondents voted for AKP and 2 voted other (the remaining 21 refused to answer). Therefore, a simple examination of the 99 respondents who mentioned some concern about democracy indicates that they were unanimous in their opposition to nullifying the first election,

overwhelmingly believed the second election was not conducted fairly, were strong supporters of the CHP, and voted in high numbers. Yet, they were just a small portion of our sample. 
To systematically test our hypotheses, we ran separate logit models on three binary dependent variables. Table 2 presents results after estimation of three logit models predicting choosing to turn out and vote (model 1), voting for AKP (model 2), and voting for CHP (model 3). Looking at the voted model, which predicts turnout, one can see that the open-ended question (i.e., where respondents mention a concern for democracy) does not reach the conventional standard of significance (i.e., $\mathrm{p}<.05$ ). Of our three variables tapping individuals' concern about democratic functioning (i.e., the top three variables in Table 2), only respondents' attitude towards nullifying the March election was significant. In this case, those agreeing with the nullification were significantly more likely to turnout than those who did not agree. This result is the opposite of what one would expect if concern for democracy were an important driver of individuals to the voting booth. Rather than energizing the opposition to go out and vote, nullification energized supporters of AKP, who did not like the result of the first election.

Reports indicate that overall AKP turnout dropped by $3.7 \%$ in the second election. Given our results that agreeing with nullifying the first election increased the probability of turning out (and voting for AKP), this suggests the drop in AKP turnout came from AKP supporters that did not support the nullification of the first election. Thus, there might be a small sign that elite antidemocratic behavior affects voters. However, staying home is not a strong sign of commitment to democracy. It is also possible that these individuals felt the AKP candidate would lose anyway (since it had just happened) and chose not to waste their time voting again. Neither of these explanations is consistent with popular news accounts of rampant support for democracy during the second election. Finally, nullification appears to have diminished the desire to participate of those who agreed with the first election results. Thus, we fail to find support for hypothesis H1a. 
Beyond our three key measures of attitudes toward the functioning of democracy, partisanship for CHP is also significant, indicating that the stronger one's identification with CHP, the more likely one is to vote. Thus, the findings support hypothesis H2a, i.e., that partisanship (support for CHP) was a significant driver of turnout, but not one's concern about the functioning of democracy. In addition, our measure of one's personal pocketbook economic beliefs does not reach statistical significance. Therefore, we fail to find support for hypotheses H3a postulating a negative relationship between perceptions of how well the economy is and partisanship.

Turning to the models predicting voting for AKP and voting for CHP, once again concern for democracy failed to reach significance in either model. In other words, of those who spontaneously mentioned some type of concern about the functioning of Turkey's democratic system, our analysis fails to show that this concern systematically drove these individuals to choose either of the two major candidates, ceteris paribus. In addition, the belief that the June election was conducted fairly increased respondents' probability of voting for AKP, whereas it does not have a significant effect on choosing CHP. Thus, attitudes towards electoral fairness are helpful for AKP, but not CHP, which is, once again, the opposite of what one would expect if concern about democratic processes were a key driver of voting behavior.

Finally, agreeing with the decision to nullify the March election has a different result than the previous two measures. As indicated in Table 2, the more one agrees with the nullification of the March election the more likely one is to vote for AKP candidate and less likely one is to vote for the CHP candidate. This is as expected, since AKP is the ruling party that orchestrated nullification and it is the one instance where we see something akin to a backlash toward AKP, as those who disagreed with the nullification were more likely to vote for 
CHP. Simply put, one's attitude toward the nullification influenced vote choices, all else equal. It is plausible that in a polarized context like Turkey, AKP voters believed that the nullification of the first election was justified because of divisive political rhetoric that portrays the other side as a threat (McCoy et al, pp 22-23). Alternatively, AKP voters might have agreed with the nullification because a CHP victory would mean the potential rupture of the clientelistic ties AKP governments have cultivated with their supporters over the years in return for their unwavering support (Esen and Gumuscu, 2020). Thus, when taken together the results of our three key variables finds support for hypothesis $\mathrm{H} 1 \mathrm{~b}$ in one instance, but not the other two.

Turning to the other standard scholarly variables predicting voting behavior, the partisanship variable performs exactly as expected. AKP voters are significantly more likely to vote for AKP and significantly less likely to vote for CHP and vice versa; thus, supporting $\mathrm{H} 2 \mathrm{~b}$. These results are also in line with the findings of Konda, a respected Turkish polling firm. Their polls suggest that Istanbul residents voted along party lines, and that the increase in İmamoğlu's votes in comparison to the 31 March elections was explained by swing voters support (Konda, 2019). Economic attitudes, once again, are insignificant, failing to support H3b. Interestingly, the more politically knowledgeable respondents are, the more likely they are to choose AKP, whereas knowledge is not a significant predictor of voting for CHP. Finally, looking at the variable frequency of watching TV news, one can see that the more TV news one watches the less likely one is to vote for AKP and the more likely one is to vote for the CHP. This is an interesting result. It suggests that news coverage drove individuals away from the ruling party despite its quantity and quality of coverage advantages. Given the popular narrative, it is not too surprising that it could have this effect. 
The two logit models predicting voting for AKP or CHP in Table 2 use a dummy variable where voting for the particular party is coded 1 and 0 otherwise. This coding choice is important and could affect our results. It means that a direct comparison between voting for AKP and CHP is muddied because the 0 code includes more than just CHP voters. One solution would be to drop respondents that voted "other" in our data. However, this is not ideal, as it further reduces the $\mathrm{N}$, eliminating important information contained in these cases. To avoid dropping cases, while also providing a direct test of the probability of choosing AKP or CHP, we estimated a multinomial logit model with a dependent variable taking on four values, that is, (1) respondent did not vote, (2) voted for AKP; (3) voted for CHP, and (4) voted other. This model allows us to make a direct comparison between voting for AKP and CHP without arbitrarily dropping any cases.

****Figure 1 here ${ }^{* * * *}$

We present the results of the multinomial model in two figures for straightforward interpretation. Figure 1 presents the average marginal effects of concern about democracy (Part A), agreeing with nullifying the March election (Part B), and agreeing that the June election was fair (Part C) on the probability of choosing not to vote, vote AKP, vote CHP, or vote other. Thus, Figure 1 allows for the easy comparison of the effects of these variables on the probability of choosing between the two major candidates. Looking at Part A of Figure 1, the point estimates with 95 percent confidence intervals for Vote AKP and Vote CHP are very similar. Thus, this data fails to support the supposition that concern about democracy will lead individuals to vote for CHP over AKP (which is hypothesis H2b). Part B tells a different story. The average marginal effect of agreeing with nullifying the March elections leads respondents to vote for AKP rather than CHP. The 95\% confidence intervals do not overlap, and neither of them 
contains zero. Agreeing with nullification is a significant positive predictor of voting for AKP and a negative predictor of voting for CHP. This is the strongest support for H2b that we find. Finally, in Part C, one can see that agreeing that the June election was conducted fairly is a significant predictor of choosing to vote for AKP, when compared to choosing to vote for CHP $(\mathrm{p}<.05)$. Indeed, the average marginal effect, according to Part $\mathrm{C}$, is to choose to vote for AKP when compared to any of the other options.

*****Figure 2 here ${ }^{* * * *}$

Figure 2 presents results similar to Figure 1, but for the variables frequency of watching TV news, social media use, and talking about politics. We highlight these two variables since media consumption is often pointed to as a driver of behavior and social media, and is given credit as an organizing force for the young. The Turkish context is also very interesting because of the bias in coverage toward AKP. Thus, seemingly, AKP should benefit from increased TV news consumption.

As Part A shows, the more days a week an individual watches TV news, the more likely one is to vote for CHP. This is true regardless of the comparison and particularly striking when compared to voting for AKP. Over the last few years, Erdoğan's semi-authoritarian regime has exerted more control over journalists and curtailed press freedoms. Yet, it appears news coverage actually hurt Erdoğan's preferred candidate. This is a surprising result, with the caveat that this data does not account for the specific programs individuals are watching. Part B also contradicts conventional wisdom. Social media use does not appear to have driven individuals away from AKP. Indeed, social media use does not appear to affect choice at all. Finally, when it comes to simply talking about politics (Part C in Figure 2) we see that the more individuals talked about it, the more likely they were to vote for either AKP or CHP. But the variable fails to find that 
talking about politics had any effect on choosing between the two major candidates in the election.

\section{Discussion}

This study shows that the effects of partisanship, and not concerns for democracy, were the primary driving force behind İmamoğlu's decisive victory in the second Istanbul mayoral election in June 2019. The popular narrative within and outside of Turkey often portrayed these elections as motivated by concerns about democratic backsliding after the nullification of the first election in March. Yet, our analysis demonstrates that very few Istanbul residents see democratic functioning as one of the most important problems facing the country. Indeed, the unprecedented cancellation of the March election's results produced the same electoral behavior that has been observed by scholars since the very first serious quantitative studies of elections began more than 70 years ago. That is, voters wear partisan glasses and they see the world through them.

There are several theoretical implications of our findings. First, our study is one of the few individual-level analyses on the concern for democracy in a polarized, competitive authoritarian context. More often than not, studies focus on authoritarian regimes' actions that lead to democratic backsliding and fail to examine the factors that affect citizens' voting behavior. In our analysis, we focus on how individual-level democratic concerns in a deeply polarized country played into Istanbul citizen's votes in the mayoral elections and find that Istanbul residents prioritized partisanship over democratic or economic concerns when casting their ballots. Thus, our analysis shows that the public may not necessarily be a reliable check 
against leaders with authoritarian tendencies. This is consistent with Svolik's argument and explains why voters support politicians in other contexts including Chávez in Venezuela, Orbán in Hungary, Putin in Russia, and Trump in the United States.

A second implication is that citizens might be more responsive to specific types of violations of democratic principles. Our analysis shows that neither the fairness of the June election nor a general concern for democracy had an impact on if and how people turned out to vote; whereas the nullification of the first round of elections did. Respondents who did not agree with the cancellation of the mayoral elections held in March were significantly more likely to vote for the opposition. Therefore, specific types of acts of democratic erosion might elicit different backlash responses at the ballot box. Of course, more study is needed in this area.

Another implication of our study is that economic dissatisfaction may not be as important a driving factor of electoral behavior in semi-authoritarian regimes as research assumes. This is somewhat surprising especially because studies show that economic concerns are at the forefront of democratic elections. In the Turkish context, the economy was in a recession at the time of the mayoral elections and citizens were already feeling the negative consequences of economic problems. The effect of economic dissatisfaction on voting behavior in competitive authoritarian regimes requires further research.

Finally, popular narratives that focus on the causes of electoral outcomes do not always capture what motivates people's voting behavior. Although the popular narrative suggested that the victory of the opposition party's candidate in the Istanbul mayoral election was a sign of the strength of Turkish democracy, our analysis is less optimistic. The prevalence of party loyalty in a deeply polarized society over democratic concerns indicates a more tenuous state of democracy in Turkey. 


\section{References:}

Akarca AT (2019) Economic voting in Turkey: single- vs. multi-party governments. Southeast European and Black Sea Studies 19(4). Routledge: 523-539. DOI: 10.1080/14683857.2019.1702621.

Almond GA and Verba S (1963) The Civic Culture: Political Attitudes and Democracy in Five Nations. Princeton, N.J: Princeton University Press.

Angelucci D, Sio LD and Paparo A (2020) Europe matters ... upon closer investigation: a novel approach for analysing individual-level determinants of vote choice across first- and second-order elections, applied to 2019 Italy. Italian Political Science Review / Rivista Italiana di Scienza Politica 50(3). Cambridge University Press: 334-349. DOI: 10.1017/ipo.2020.21.

Aytaç SE and Çarkoğlu A (2018) Presidents Shaping Public Opinion in Parliamentary Democracies: A Survey Experiment in Turkey. Political Behavior 40(2): 371-393. DOI: 10.1007/s11109-017-9404-X.

Bansak K, Hainmueller J, Hopkins DJ, et al. (2021) Beyond the breaking point? Survey satisficing in conjoint experiments. Political Science Research and Methods 9(1). Cambridge University Press: 53-71. DOI: 10.1017/psrm.2019.13.

Bartels LM (2000) Partisanship and Voting Behavior, 1952-1996. American Journal of Political Science 44(1). [Midwest Political Science Association, Wiley]: 35-50. DOI: $10.2307 / 2669291$.

Bartkowska M and Tiemann G (2015) The Impact of Economic Perceptions on Voting Behaviour in European Parliamentary Elections. JCMS: Journal of Common Market Studies 53(2): 201-217. DOI: 10.1111/jcms.12158.

Bermeo N (2016) On Democratic Backsliding. Journal of Democracy 27(1): 5-19. DOI: 10.1353/jod.2016.0012.

Berz J (2020) The effect of voters' economic perception, Brexit and campaigns on the evaluation of party leaders over time. The British Journal of Politics and International Relations 22(2). SAGE Publications: 202-219. DOI: 10.1177/1369148119886220.

Çakır S (2019) Polarized partisanship, over-stability and partisan bias in turkey. Turkish Studies 0(0). Routledge: 1-27. DOI: 10.1080/14683849.2019.1678030.

Driscoll A and Nelson MJ (2014) Ignorance or Opposition? Blank and Spoiled Votes in LowInformation, Highly Politicized Environments. Political Research Quarterly 67(3). SAGE Publications Inc: 547-561. DOI: 10.1177/1065912914524634. 
Edy JA and Meirick PC (2018) The Fragmenting Public Agenda: Capacity, Diversity, and Volatility in Responses to the "Most Important Problem" Question. Public Opinion Quarterly 82(4). Oxford Academic: 661-685. DOI: 10.1093/poq/nfy043.

Esen B and Gümüşçü S (2016) Rising competitive authoritarianism in Turkey. Third World Quarterly 37(9). Routledge: 1581-1606. DOI: 10.1080/01436597.2015.1135732.

Esen B and Gümüşçü S (2019) Killing Competitive Authoritarianism Softly: The 2019 Local Elections in Turkey. South European Society and Politics 24(3). Routledge: 317-342. DOI: 10.1080/13608746.2019.1691318.

Esen B and Gumuscu S (2020) Why did Turkish democracy collapse? A political economy account of AKP's authoritarianism. Party Politics. SAGE Publications Ltd: 1354068820923722. DOI: 10.1177/1354068820923722.

Fleury CJ and Lewis-Beck MS (1993) Anchoring the French Voter: Ideology versus Party. The Journal of Politics 55(4). [University of Chicago Press, Southern Political Science Association]: 1100-1109. DOI: 10.2307/2131950.

Freedom House (2019) Turkey. Available at: https://freedomhouse.org/country/turkey/freedomworld/2019 (accessed 24 June 2020).

Gall C (2019) Turkey's President Suffers Stinging Defeat in Istanbul Election Redo (Published 2019). The New York Times, 23 June. Available at: https://www.nytimes.com/2019/06/23/world/europe/istanbul-mayor-electionerdogan.html (accessed 31 December 2020).

Gandhi J and Lust-Okar E (2009) Elections Under Authoritarianism. Annual Review of Political Science 12(1). Annual Reviews: 403-422. DOI:

10.1146/annurev.polisci.11.060106.095434.

Geddes B, Wright JG, Wright J, et al. (2018) How Dictatorships Work: Power, Personalization, and Collapse. Cambridge University Press.

Hoerner JM and Hobolt SB (2019) Unity in diversity? Polarization, issue diversity and satisfaction with democracy. Journal of European Public Policy 0(0). Routledge: 1-20. DOI: 10.1080/13501763.2019.1699592.

Human Rights Watch (2020) World Report 2020: Rights Trends in Turkey. Available at: https://www.hrw.org/world-report/2020/country-chapters/turkey (accessed 30 December 2020).

Iyengar S and Westwood SJ (2015) Fear and Loathing across Party Lines: New Evidence on Group Polarization. American Journal of Political Science 59(3): 690-707. DOI: 10.1111/ajps.12152. 
Kadığlu, A (2019) Istanbul mayoral elections: in praise of human agency. Available at: https:/www.opendemocracy.net/en/can-europe-make-it/istanbul-mayoral-electionspraise-human-agency/ (accessed 24 June 2020).

Kalaycıoğlu E (2014) Local Elections and the Turkish Voter: Looking for the Determinants of Party Choice. South European Society and Politics 19(4). Routledge: 583-600. DOI: 10.1080/13608746.2014.993511.

Kalmoe NP and Piston S (2013) Is Implicit Prejudice against Blacks Politically Consequential? Evidence from the AMP. Public Opinion Quarterly 77(1). Oxford Academic: 305-322. DOI: $10.1093 / \mathrm{poq} / \mathrm{nfs} 051$.

Karp JA and Lühiste M (2016) Explaining Political Engagement with Online Panels: Comparing the British and American Election Studies. Public Opinion Quarterly 80(3): 666-693. DOI: $10.1093 / \mathrm{poq} / \mathrm{nfw} 014$.

Kemahlığlu Ö and Özdemir E (2018) Municipal control as incumbency advantage: an analysis of the AKP era. In: Sayar1 S, Ayan Musil P, and Demirkol Ö (eds) Party Politics in Turkey: A Comparative Perspective. London: Routledge, pp. 116-135. Available at: http://research.sabanciuniv.edu/36081/ (accessed 28 May 2020).

Konda (2019) Konda | 23 Haziran 2019 Sandık Analizi ve Seçmen Profilleri. Available at: https://konda.com.tr/tr/rapor/23-haziran-2019-sandik-analizi-ve-secmen-profilleri/ (accessed 28 May 2020).

Levitsky S and Way L (2002) The Rise of Competitive Authoritarianism. Journal of Democracy 13(2): 51-65. DOI: 10.1353/jod.2002.0026.

McCoy J, Rahman T and Somer M (2018) Polarization and the Global Crisis of Democracy: Common Patterns, Dynamics, and Pernicious Consequences for Democratic Polities. American Behavioral Scientist 62(1). SAGE Publications Inc: 16-42. DOI: $10.1177 / 0002764218759576$.

McKernan B (2019) Erdoğan party defeated in controversial rerun of Istanbul mayoral poll. The Guardian, 23 June. Available at: https://www.theguardian.com/world/2019/jun/23/erdogan-faces-scrutiny-once-more-asistanbul-goes-back-to-the-polls (accessed 28 May 2020).

Meeusen C, Boonen J and Dassonneville R (2017) The Structure of Prejudice and Its Relation to Party Preferences in Belgium: Flanders and Wallonia Compared. Psychologica Belgica 57(3). 3. Ubiquity Press: 52-74. DOI: 10.5334/pb.335.

Paparo A, De Sio L and Brady DW (2020) PTV gap: A new measure of party identification yielding monotonic partisan attitudes and supporting comparative analysis. Electoral Studies 63: 102092. DOI: 10.1016/j.electstud.2019.102092. 
Passini S (2017) Different Ways of Being Authoritarian: The Distinct Effects of Authoritarian Dimensions on Values and Prejudice. Political Psychology 38(1): 73-86. DOI: 10.1111/pops. 12309 .

Sayar1 S (2016) Back to a Predominant Party System: The November 2015 Snap Election in Turkey. South European Society and Politics 21(2). Routledge: 263-280. DOI: 10.1080/13608746.2016.1170254.

Sendika.Org (2019) İHD’den seçim öncesi ihlal raporu. Available at: https://sendika63.org/2019/03/ihdden-secim-oncesi-ihlal-raporu-540045/ (accessed 24 June 2020).

Somer M (2019) Turkey: The Slippery Slope from Reformist to Revolutionary Polarization and Democratic Breakdown. The ANNALS of the American Academy of Political and Social Science 681(1). SAGE Publications Inc: 42-61. DOI: 10.1177/0002716218818056.

Svolik M (2020) When Polarization Trumps Civic Virtue: Partisan Conflict and the Subversion of Democracy by Incumbents. ID 3243470, SSRN Scholarly Paper. Rochester, NY: Social Science Research Network. DOI: 10.2139/ssrn.3243470.

Svolik MW (2012) The Politics of Authoritarian Rule. Cambridge University Press.

Svolik MW (2019) Polarization versus Democracy. Journal of Democracy 30(3). Johns Hopkins University Press: 20-32. DOI: 10.1353/jod.2019.0039.

The Economist (2019a) The new depths of Erdogan's autocracy. The Economist, 9 May. Available at: https://www.economist.com/leaders/2019/05/09/the-new-depths-oferdogans-autocracy (accessed 28 May 2020).

The Economist (2019b) Turkey's President Erdogan accuses the West of terrorism. The Economist, 28 March. Available at:

https://www.economist.com/europe/2019/03/28/turkeys-president-erdogan-accuses-thewest-of-terrorism (accessed 28 May 2020).

Toktamis KF and David I (2018) Repression and resistance - fragments of Kurdish politics in Turkey under the AKP regime. Turkish Studies 19(5). Routledge: 661-670. DOI: 10.1080/14683849.2018.1508350.

Valentino NA, Zhirkov K, Hillygus DS, et al. (2020) The Consequences of Personality Biases in Online Panels for Measuring Public Opinion. Public Opinion Quarterly 84(2): 446-468. DOI: $10.1093 / \mathrm{poq} / \mathrm{nfaa} 026$.

van der Eijk C, van der Brug W, Kroh M, et al. (2006) Rethinking the dependent variable in voting behavior: On the measurement and analysis of electoral utilities. Electoral Studies 25(3): 424-447. DOI: 10.1016/j.electstud.2005.06.012. 